\title{
Correction to: An open-label, randomized, placebo-controlled study on the effectiveness of a novel probiotics administration protocol (ProbiotiCKD) in patients with mild renal insufficiency (stage 3a of CKD)
}

\author{
Mariadelina Simeoni ${ }^{1} \cdot$ Maria Lucia Citraro ${ }^{1}$. Annamaria Cerantonio ${ }^{1} \cdot$ Francesca Deodato $^{1} \cdot$ Michele Provenzano $^{1}$. \\ Paola Cianfrone ${ }^{1}$ - Maria Capria ${ }^{1}$. Silvia Corrado ${ }^{1}$ - Emanuela Libri ${ }^{1}$ - Alessandro Comi ${ }^{1}$ - Arturo Pujia ${ }^{2}$. \\ Ludovico Abenavoli ${ }^{3} \cdot$ Michele Andreucci $^{1} \cdot$ Massimo Cocchi ${ }^{4} \cdot$ Tiziana Montalcini $^{2} \cdot$ Giorgio Fuiano ${ }^{1}$
}

Published online: 9 October 2018

(C) The Author(s) 2018

\section{Correction to: European Journal of Nutrition https://doi.org/10.1007/s00394-018-1785-z}

In the original publication of the article, few of the authors were missed in the author group.

The correct author group is mentioned above. The original article has been corrected.
Open Access This article is distributed under the terms of the Creative Commons Attribution 4.0 International License (http://creativeco mmons.org/licenses/by/4.0/), which permits unrestricted use, distribution, and reproduction in any medium, provided you give appropriate credit to the original author(s) and the source, provide a link to the Creative Commons license, and indicate if changes were made.

The original article can be found online at https://doi.org/10.1007/ s00394-018-1785-z.

Mariadelina Simeoni

adelina.simeoni@unicz.it; adelina_simeoni@yahoo.it

1 Nephrology Unit, Department of Surgical and Medical Science, 'Magna Graecia' University Hospital, Viale Europa, Germaneto Area, 88100 Catanzaro, CZ, Italy

2 Clinical Nutrition Unit, 'Magna Graecia' University Hospital, 88100 Catanzaro, CZ, Italy

3 Digestive Physiopathology Unit, 'Magna Graecia' University Hospital, 88100 Catanzaro, CZ, Italy

4 "Paolo Sotgiu" Institute for Research in Quantitative and Quantum Psychiatry and Cardiology, LUdeS, Lugano, Switzerland 